\title{
Short Stories against Barcelona's Urban Transformation
}

Edgar Illas

\section{(2) OpenEdition}

\section{Journals}

\section{Electronic version}

URL: http://journals.openedition.org/transtexts/142

DOI: $10.4000 /$ transtexts. 142

ISSN: 2105-2549

\section{Publisher}

Gregory B. Lee

\section{Printed version}

Date of publication: 1 September 2007

Number of pages: 84-97

ISSN: 1771-2084

\section{Electronic reference}

Edgar Illas, "Short Stories against Barcelona's Urban Transformation », Transtext(e)s Transcultures 跨 文本跨文化 [Online], 3 | 2007, Online since 15 October 2009, connection on 20 April 2019. URL : http:// journals.openedition.org/transtexts/142 ; DOI : 10.4000/transtexts.142 


\title{
Short Stories against Barcelona's Urban Transformation
}

\author{
EDGAR ILLAS
}

The Olympic Games of 1992 launched Barcelona as one of the most fashionable and appealing cities in the world. In preparation for the Games, the city experienced during the 1980s a deep symbolic, political, and architectural transformation which turned Barcelona into a prosperous global city, but also aimed to reconcile this modernization trend with the recovery of her rich historical past and cultural heritage. Fictional narratives set in cities often relive the spaces, streets or characters that have disappeared because of unremitting processes of urban change. Many narratives struggle in this way against the erasure of spatial and collective memory. My article argues that, in the case of Catalan author Quim Monzó, we encounter exactly the opposite. In his short stories written during 1980s and early 90s, Monzó portrays a standardized, almost unrecognizable Barcelona--a "generic city," to use Rem Koolhaas' term,--full of characters with no sense of historical past. His portrait contests the official retrieval of the city's past as it reveals how this recovery has implied the commodification of history and, in a dialectical move, its ultimate erasure. Through Monzó's fiction, we can observe how history has become another aspect of the cities' advertisement of themselves as a differentiated trademark in the global market.

In preparation for the 1992 Olympic Games, Barcelona experienced during the 1980s a deep process of urban transformation. Barcelona's urban fabric had been terribly affected by indiscriminate construction and real estate speculation in the previous decades, under Francisco Franco's dictatorship. After the dictator's death in 1975, democracy came to Spain, Catalonia recuperated its autonomous 
government of the Generalitat de Catalunya, and Barcelona elected a socialist city government. In this context, architect Oriol Bohigas became in 1980 the urban designer of Barcelona's city council and launched a plan to rebuild a city that had been torn apart by busy highways and intense urban sprawling.

Bohigas, who exposed in various books his program to foster urban compactness and multifunctionality, proclaimed a precise slogan that summarized his plan: «ens cal higienitzar el centre i monumentalitzar la perifèria» [«we must clean up the center and monumentalize the periphery»]. ${ }^{1}$ On the one hand, his project stipulated minimal but conscientious interventions that would «esponjar» the city, that is, that would sponge the urban fabric and open up public spaces in densely populated areas. No overall demolition was necessary - only a sensitive intervention in concrete points. On the other hand, to monumentalize the periphery referred to two specific things. First, high-speed roads and expressways had to be integrated into the city fabric instead of letting them tear it up and alienate entire neighborhoods. Second, landmarks were necessary to give a distinctive personality to streets and neighborhoods. Hence, public sculptures by internationally recognized figures were placed in the less glamorous areas of the city. Richard Serra, Claes Oldenburg, Roy Lichtenstein, Joan Miró, Ellsworth Kelly, Eduardo Chillida, Bryan Hunt, Jannis Kounellis, Jaume Plensa, Rebecca Horn, Frank Gehry, Fernando Botero, Antoni Tàpies, or Joan Brossa, among many others, provided works at unusually reasonable prices because of the public and revitalizing function they would fulfill. ${ }^{2}$

Bohigas' plan aimed to create new and diversified centers throughout the city. The strategic re-equipment of specific spaces intended to have «efectes osmòtics» [«osmotic effects»] over larger areas. ${ }^{3}$ New parks, museums, restored monuments, street sculptures, renovated old squares, and, most notably, pristine beaches were devised to regenerate degraded zones, provide more public spaces, and help citizens map the city easily. These centers, or also called «areas of new centrality», would divide the city in well-defined, understandable sections most of which would coincide with the limits of historical neighborhoods. Thus, the plan intended to bring back a sense of place or, as Mayor Pasqual Maragall put it, to help the city recover itself. ${ }^{4}$ The transformation would make the city more distinctive, more

${ }^{1}$ Oriol Bohigas, Reconstrucció de Barcelona, Bacelona: Edicions 62, 1985, p. 65.

${ }^{2}$ For a full list of the artists and sculptors and their works, see Subirós, Pep, El vol de la fletxa: Barcelona 92:

Crònica de la reinvenció de la ciutat, Barcelona: CCCB/Electra, 1993, pp. 128-131.

${ }^{3}$ Oriol Bohigas, Reconstrucció de Barcelona, p. 101.

4See Pasqual Maragall, La ciutat retrobada, Barcelona: Edicions 62, 1991. 
compact, more public, easier to read, and, not least, prettier, to quote the municipal slogan advertising the renewal «Barcelona, posa't guapa» [«Barcelona, make yourself pretty»]. And, according to the amount of attention and awards that the city received, among them the Gold Medal from the Royal Institute of British Architects in 1999, the municipal government did achieve the goals of Bohigas' plan, which soon became known as «the Barcelona model» of urban transformation.

Generally, when a deep process of urban change occurs, many fictional narratives quickly come out eager to retrieve the spaces on the verge of disappearing and the collective memory embodied in them. These narratives often function as compensatory devices for the momentary sense of loss and disorientation caused by the new urban landscape. Even if their representation of a collective memory might seem to contest the urban change, they rather reinforce the new state of things, as these narratives reassure everyone that the past may be erased from the streets but it will be preserved in their pages. ${ }^{5}$

But in the relation between Barcelona and Quim Monzó, one of the most popular Catalan writers of the 1980s and 90s, we encounter the opposite. Monzó's short stories not only do not allude to any past times but in fact they hardly refer to Barcelona. Unlike any other writer before him, Monzó depicts Barcelona as a dehistoricized city made of a series of standard and anonymous settings. His Barcelona is a spectral city with atemporal places where citizens are identifiable only as grammatical traces, clothing brands, or social stereotypes.

Only a few arbitrary signs allow the reader to identify Monzó's urban landscape as Barcelona's. L'illa de Maians [The Maians Island] is the enigmatic title of a 1985 short stories collection that refers to an island that up until the fifteenth century existed as a barrier between Barcelona and the Mediterranean. ${ }^{6}$ Later, layers of sedimentation incorporated the island into the current extension of the old quarter and the island became a spectral reference to a forgotten past. Also, this collection is divided in three parts titled with oblique allusions to Barcelona: «Carrer dels dies feiners» [«Working Days Street»], an extinct popular designation of a Barcelona street; «A handkerchief or neckerchief of soft twilled silk», which is one of the meanings of the word «Barcelona» according to the Oxford English Dictionary; and «La Casa

\footnotetext{
In Barcelona, we can find two representative examples of these narratives in Francisco Casavella's novel El triunfo, Barcelona: Anagrama, 1990, which portrays the disappeared street gangs of the old neighborhood of the Raval, or in Juan Marsé's Ronda del Guinardó, Barcelona: Seix Barral, 1990, which similarly portrays the miserable life of a family who lives at the outskirts of the city during the decades previous to the Olympic transformation.

'Quim Monzó, L'illa de Maians, Barcelona: Quaderns Crema, 1985.
} 
de la Estilográfica», a reference to a disappeared office supplies store. ${ }^{7}$ The thirty stories of another collection, El perquè de tot plegat [The Reason of Everything], ${ }^{8}$ do not contain any location mark except for one, a "cafeteria a la Diagonal" - a cafeteria in one of the avenues of Barcelona's Eixample, where two characters have a drink. Finally, there is not a single reference to Barcelona in the last collection of short stories that I will examine. The title of this collection, Guadalajara (1996), although inspired by the well-known Mariachi song, even enigmatically alludes to two other cities, the homonymous cities in Spain and Mexico.

In Monzó's stories, spaces are simply designated as a generic apartment, a hotel room, a bar, a street, a highway, or a hospital. In the few cases in which spaces are described, the specifications consist of a plain list of the - serialized - objects contained in them. For example, a hotel room:

«Els donen una habitació amb dos llits individuals, dues tauletes de nit, una taula per escriure (hi ha sobres i paper de carta amb la capçalera de l'hotel, en una carpeta), una cadira i un minibar amb un televisor al damunt.» ${ }^{9}$

[They assign them a room with two twin beds, two bedside tables, a desk (there are envelopes and sheets with letterheads from the hotel, in a folder), a chair and a minibar with a TV on top.]

This hotel is just located in an unnamed «ciutat llunyana» [《far-away city»]. And, although occasionally we find references to real cities, regions, and states, there is never a detailed description or implied justification of why these cities are mentioned. ${ }^{10}$

In another story, a man is in a woman's apartment, the location of which is never specified. He even acknowledges the difficulty of describing the place:

\footnotetext{
7Julià Guillamon deciphers these oblique allusions in La ciutat interrompuda: de la contracultura a la Barcelona postolímpica, Barcelona: La Magrana, 2001, pp. 188-9.

${ }^{8}$ Quim Monzó, El perqué de tot plegat, Barcelona, Quaderns Crema, 1992.

${ }^{9}$ Quim Monzó, El perqué de tot plegat, p. 21.

${ }^{10}$ Some of the mentioned cities are, among others, the Italian Castagnaro, Casteggio, Voguera,

Alessandria, Piacenza (1985: 48), and Bergamo, Marseille, Milano, Bordeaux, Lyon, Bilbao, Toulouse, Strasbourg (1985: 53), Aberdeen (1992: 30), Florence, Pisa (1992: 43) or Birmingham (1996: 165). Perhaps the fact that all these cities are, like Barcelona, European and not state capitals is not arbitrary. But we can also find Brussels (1985: 53), Rome (1992: 56), Paris (1996: 161), or Berlin (1996: 169); and the regions of New Scotland (1992: 49), Mallorca (1992: 87), the Aegean Islands (1996:167), or Hawaii (1996:168); and the states Laos, Cambodia, Thailand (1996: 163), Chile, or Japan (1996: 168).
} 
«Eren a ca la noia, i si li haguessin demanat de descriure-la, no hauria sabut com fer-ho. De cua d'ull va mirar el llarg moble de fusta clara, envernissat; va veure-hi un plat de ceràmica brillant, un tambó marroquí, un tub d'aspirines, tres llibres i una pipa blanca holandesa.» 11

[They were at her house, and if he had been asked to describe it, he would not have known how to do it. He looked obliquely at the light-colored, varnished large piece of furniture; on it he could see a shiny pottery plate, a Moroccan drum, an aspirin tube, three books and a white Dutch pipe.]

Characters are also designated by generic labels. In most cases they are simply a man, a woman, a boy, or a girl. Further specifications consist of a color, such as «l'home blau» [«the blue man»] and «l'home magenta» [《the magenta man»]; an adjective, as in «la dona fatal» ["the femme fatale"] and «l'home irresistible» [«the irresistible man»]; or an unutterable, agrammatical name, such as 〈Grmpf» and «Pti». ${ }^{12}$ These labels depict the characters as empty stereotypes lacking what is conventionally known as personality or an inner self. They visibly embody the three features that Fredric Jameson finds in postmodern cultural artifacts: flatness or depthlessness, a deathly quality, and the waning of affect. ${ }^{13}$ These characters are both superficial and unfathomable, offering no access to any individual inside or to any supposedly «personal feelings.» 14

This disidentification with any particular location or historical context contrasts with a manifest feature of Monzó's stories, namely the fact that they are written in Catalan. As a minority and stateless language, Catalan is immediately associated

\footnotetext{
${ }^{11}$ Quim Monzó, L'illa de Maians, p. 12.

${ }^{12}$ Quim Monzó, El perqué de tot plegat, pp. 55, 49, 27.

${ }^{13}$ Fredric Jameson, Postmodernism, Or, The Cultural Logic of Late Capitalism, Durham NC: Duke University Press, 1991, pp. 9-11

${ }^{14} \mathrm{An}$ extreme and amusing example of the depiction of characters as stereotypes is the series of random traits used to describe a «man» in the story «L'eufòria dels troians» (1992: 83-97). Along the story, he is characterized as: «L'home que durant la infantesa havia tingut una certa fe religiosa»; «l'home que a la infantesa s'havia interessat per la matemàtica»; «l'home que a la infantesa havia tingut problemes d'inadaptació»»; «l'home que va tenir de noi una caçadora de pell de la qual encara es recorda» 〈l'home que de noi va anar a Mallorca de viatge de fi de curs l'últim any de batxillerat»; «l'home que d'adolescent s'emprovava davant del mirall de l'armari els sostenidors de sa mare»; «l'home que va tenir la primera nòvia als quinze anys»; etc. ["The man who during his childhood had a certain religious faith;" «the man who during his childhood was interested in mathematics»; «the man who during his childhood had adaptation problems»; « «the man who as a teenager had a leather jacket that he still remembers»; « «the man who traveled to Mallorca in his last year of high school»; « the man who as a teenager would try on his mother's bra in front of the mirror»; « the man who had his first girlfriend when he was fifteen»; etc.] The evident effect is that his whole biography consists of a succession of random stereotypical features.
} 
with an actual region, a distinct community, and even with Catalan nationalism. The Catalan language can hardly be detached from a very specific territory and political history. Thus, this inherent tension between the unidentified characters and spaces and the highly particularizing language of the stories can be interpreted as an attempt to create an imaginary of Barcelona and Catalonia as fully globalized places that still maintain a vernacular language. In this sense, Monzó's standard, easily transportable and even universalizable characters and urban spaces would denote an eagerness to avoid provincialism and the association of Catalan culture with tradition, folklore, or the countryside. In other words, he deals with this underlying anxiety of a minority culture in front of globalization by precisely portraying and endorsing, in Catalan, the homogenizing global forces. This way he implicitly attests that Catalan can function in this new context too.

The stories can also be inscribed in the context of transitional Spain. From this viewpoint, Monzó's stereotypical and unidentified spaces and characters aim to create a literary representation compliant with the pacto del olvido of the postdictatorship transition. This tacit pact emerged from the will to quickly forget Spain's Francoist years and the aspiration to abandon the country's ancestral semi peripheral condition. In this context, Monzó's stories provided an appealing and timely imaginary for Catalans to begin perceiving themselves and their territory in accordance with the homogeneous appearance of the new global world - which maybe helps explain the stories' widespread success.

But there is one fundamental component of the stories that must be understood in relation to the new urban reality of Barcelona rather than in relation to their Catalan and Spanish contexts. This component is the circular plots, the claustrophobic spaces, the Moebius strips from which characters of the stories cannot escape. In Monzó's fiction, circular enclosures are omnipresent at all levels, from the plots to the spaces they inhabit. For instance, in «L'amor» [«Love»] ${ }^{15}$ an archivist treats with disdain and coldness the soccer player she is dating. He is madly in love with her and keeps insisting that she should not be afraid of expressing her true feelings for him. When, after months of treating him cruelly, she finally gives herself over to him and proposes to move in together, he cannot help reacting with coldness and disdain. Or, in «Halitosi» [«Halitosis»],16 a man's breath is so bad-smelling that he has to isolate himself from society until nobody is able to tell him that his breath has just stopped smelling bad. Or the Kafkian «Gregor» is the story of a bug that

${ }^{15}$ Quim Monzó, El perqué de tot plegat, pp. 17-20.

${ }^{16}$ Quim Monzó, L'illa de Maians, pp. 105-119 
wakes up one morning transformed into a human being whose first human act is to smash three disgusting bugs that he finds in the closet. ${ }^{17}$

These characters are trapped in worlds, and specifically in urban worlds, that are oppressively closed but also painlessly flat. Monzó's world is tragic but does not produce any romantic wreckages; it is hopeless but without any modernist seclusions, absurd but with no existentialist Sisyphean chains. In this sense, the stories' verbs in the present tense must be understood as the temporal correspondence of these spatial enclosures. This predominant present tense suggests that the characters inhabit a perpetual present with no sense of the past or the future, with neither unsettled traumas nor secret longings.

At the beginning of the illustrative story «La força centrípeta» [《The Centripetal Force»], a man is unable to leave his apartment because when he opens the outside door he encounters the same hall he is trying to leave. Then, two firemen go to rescue him but get stuck in the same circle. At this point, the man can successfully leave the apartment. The firemen can also leave the apartment but not the building, as the stairs begin to reproduce themselves endlessly. Meanwhile, a neighbor is killed and, after some panic and screams, the other neighbors in the building attribute the crime to the firemen, who cannot offer a plausible alibi in their defense. The story ends with the hearse that carries the coffin with the dead neighbor and his family driving around the city in circles unable to find the cemetery. The city is totally unrecognizable:

«Són en una zona de la ciutat plena de magatzems. Són illes i illes de cases $\mathrm{amb}$ naus industrials i camions (enormes) aparcats. Els carrers tenen noms desconeguts per la majoria de ciutadants, ells inclosos. $>^{18}$

[They are in an area of the city full of warehouses. There are blocks and blocks of houses with industrial plants and (enormous) trucks parked. The streets' names are unknown to most of the citizens, including them.]

In the end, the hearse driver finally admits that he does not know where they are and tries to go back to their starting point,

«Però no hi ha manera d'arribar-hi i es troben, de cop, en una plaça quadrada.

És una plaça que du el nom d'un general de fa un parell de segles, amb un

${ }^{17}$ Quim Monzó, Guadalajara, Barcelona, Quaderns Crema, 1996, pp. 49-57.

${ }^{18}$ Quim Monzó, p.124 
gran arbre de tronc retorçat al bell mig, al damunt del qual dos nens juguen a fer caure l'altre, i on no va a parar cap carrer tret d'aquell del qual vénen.>19

[But there is no way of getting there and they suddenly find themselves in a square. It is a square that bears the name of a general from a couple of centuries ago, with a big, twisted tree in its center, on top of which two kids are playing to make the other fall, and where no street ends except for the one they come from.]

In this claustrophobic metropolis, houses, streets and neighbors are totally unidentified. Most citizens do not recognize the street names, or the name of the square referring to an also unnamed historic general does not help the characters locate themselves either.

The same urban traits can be found in the story «Casa amb jardí» [«House with Garden»], set in a claustrophobic and homogeneous residential suburb. In this story, a man leaves work and returns to his home, a two-story, single-family house in a suburban villa. The dog and the woman welcome him, he licks his hand, she kisses his lips. Then he sits on the couch to work on a crossword while she begins to watch TV. But, all of a sudden, he realizes that the woman sitting next to him is not his wife, that he has never owned a pet, and that that is not his house. Astounded, he wonders how he could possibly miss these changes and why the strange woman is acting so normal as if she was his wife. He knows that he is not suffering amnesia, because he can perfectly remember his real wife. He notices that the house is identical to his, like each one in that villa. He looks out the window and sees the same landscape he would see from his house. He knows he could leave or at least check the house number, but «fer-ho li fa por: ignora per què, però no sent cap desig de comprovar què passa», [«he is afraid of doing it: he does not know why, but he does not feel like checking out what is going on»»] In the end, he imagines when he and the woman will go to bed together later, and «[a]quest pensament li produeix, de forma immediata, una erecció $»,[\ll$ This thought produces in him an immediate erection. $\gg]^{20}$

This relatively happy ending provides a twist that opens up the possibility of escaping this dystopia: the possibility of enjoying the very indeterminacy and interchangeability of this urban landscape. Sexual excitement represents here the acceptance of the current hopeless circumstances but also points at the beginning of a potential journey of discovery and new exchanges. Sex, a ubiquitous theme in

${ }^{19}$ Quim Monzó, p. 127

${ }^{20}$ Quim Monzó, L'illa de Maians, pp. 19, 21 
Monzó's stories, seems to provide one of the few ways to cope with the inexorability of this dystopian situation.

However, a later story cancels out even this possibility. In «La gelosia" [《Jealousy»], a man enjoys how a woman is praising, touching and licking his penis. But she does it so insistently and obsessively that the situation begins to distress him. He finally asks her whether his penis is the only thing in which she is interested, and suddenly all her devotion turns into anger. She calls him crazy, gets dressed and leaves, while he «s'asseu al llit, es posa la mà dreta sota el membre, flàccid, l'alça una mica i el contempla, entre furiós i encuriosit»», [«he sits on the bed, puts his right hand under his flaccid penis, lifts it and contemplates it with fury and curiosity».] ${ }^{21}$ Thus, while in «Casa amb jardí»» the final erection opened a certain possibility to establish new relations and live new experiences, here the flaccid member, despite awakening curiosity to his possessor, becomes a mere remainder of a thwarted relation, a burdensome piece that objectifies the subject who holds it. The penis stands as an impediment to establish any subjective - let alone collective - connection.

In his study of Barcelona's cultural production of the 1980s and 90s, La ciutat interrompuda, Julià Guillamon remarks that Monzó's fiction paradigmatically portrays Barcelona as an "interrupted city," that is, as a city with an erased sense of the past and with no historical memory. In relation to Monzó's short stories, however, this suggestive concept of the «interrupted city» must be expanded and unfolded in at least two ways. ${ }^{22}$

On the one hand, Monzó's depiction of an «interrupted» Barcelona - or of what remains of Barcelona in the scattered and oblique location marks contained in his short stories - contrasts with the official transformation of the city during the 1980s, which involved an overall and unprecedented restoration of its historical and architectural heritage. Monzó's dehistoricized Barcelona coincides with the period when the city began to be most aware and most fond of its past. On the other hand, in Monzó this temporal interruption comes with precisely the opposite in spatial terms: the presence of an uninterrupted city, a city that has spread everywhere

\footnotetext{
${ }^{21}$ Quim Monzó, El perqué de tot plegat, p.61. Erections have a nuclear function in much of Monzó's fiction. His novel La magnitud de la tragèdia (1989) narrates the story of a man who suffers a deadly disease that gives him a permanent erection. For a gender studies critique of Monzó's representation of males in crisis, see Josep-Anton Fernàndez, «Magnituds comparades: Els destrets de la masculinitat i la crisi de l'autoria a dues novel les de Quim Monzó», Calçasses, gallines i maricons, eds. Josep-Anton Fernàndez and Adrià Chavarria, Barcelona: Angle, 2003, pp. 34-57.

${ }^{22}$ Julià Guillamon, La ciutat interrompuda, p. 188.
} 
leaving no space for any - rural, natural, non-urban- outside. Such a representation of Barcelona as an uninterrupted and disidentified city thus contrasts with the official re-imagining and re-building of it as an idiosyncratic and highly appealing place.

David Harvey, in his The Condition of Postmodernity, explains how, since in postmodern times the extraction of surplus-profits comes from the productivity of multinational companies and the competition between them rather than from territorial natural differences, now territories must compete among themselves to attract investments from transnational capital. Cities, regions, or states must make themselves attractive in order to bring into their territory those headquarters, tourists, manufacturers, conventions, or services which, given their mobile nature, can potentially be placed anywhere. Harvey defines these strategies of differentiation of spaces as an «active production of places with special qualities».23 This production fabricates and advertises the characteristics that make a place peculiar and idiosyncratic.

So, if the production of city identity is part of the strategies to attract investments from transnational capital, then does Monzó's uninterrupted and dystopian city not embody the uninterrupted flows of global capital that determine the territorial transformations in late capitalism? In the same way that the forces of highly mobile capital run beneath the configuration of the world as a series of «special places, Monzó's dystopian city reveals the real material changes that have taken place beneath Barcelona's acclaimed urban transformation.

Another significant story is titled «Barcelona», although it does not contain any further element that links it to the real city. In it, a man and a woman talk. She complains that he is not listening to her. She says that both nights they have spent together he has only talked about himself and has never asked about her, about who she is or what she does. After some moments of perplexity, he eventually reacts and apologizes. He says that he had never realized how self-centered he could be and that he cannot stand egotistic people. He says that he needs her to help him find out why and when he behaves this way. In the end, he says,

«... voldria saber què, o quin seguit de coses han fet de mi un egotista. ...

m'agradaria deixar de ser així amb tu ... Perquè m'interesses molt. Per això

23David Harvey, The Condition of Postmodernity, Oxford: Blackwell, 1992, p. 295. 
necessito que m'ajudis a descobrir en quines ocasions em comporto Aixa ... I perquè ho faig. M'agradaria que en parléssim.» ${ }^{24}$

[I'd like to know what, or what sort of things have made me an egotistic person. ... I would like to stop being this way with you ... Because I'm interested in you. That's why I need you to help me find out when I behave this way, and why I do it. I would like to talk about it with you.]

The fact that Monzó titled this story «Barcelona» can be simply interpreted as a boutade about the typical egotism of Barcelonans - the same that is often said about New Yorkers or Parisians. But there is also another possibility, namely that Barcelona is an egotistic city talking all the time about itself. If the «active production of places with special qualities» involves the fabrication and advertising of the characteristics that make a place peculiar, does this egotistic character not symptomatize Barcelona's new investment in its own self-absorbed differentiation as an identifiable place? That is, Monzó's character reveals how the competition among cities to attract global capital produces the effect that, like the man of the story, cities are always talking about themselves. The cities' official promotion as cosmopolitan and receptive places - and Barcelona has intensely used these labels to characterize itself through its politics of creation of public spaces - ultimately reveals, not a will to open themselves to whichever others, but a strategy to advertise themselves and attract global capital, in the same way that the man is interested in the woman only to keep being wrapped up around himself.

This necessity of cities and territories to produce their own differential qualities indicates precisely a structural homogenization caused by this very production. Territories are manufactured, serialized and sold like any other commodity. They are expressed as exchange values and therefore the presumed singularity they might contain is dissolved in the structural generality of the market. Once again, the paradox is that, in the postmodern context, the production of a sense of place and of spatial identity causes the standardization and the dedifferentiation of that very place.

This is the truth that Monzó's short stories reveal about Barcelona: its renovation and the rehabilitation of its historical past has standardized and commodified the city rather than returning it to its people. In the stories, all the specificity that is left of Barcelona is some scattered location markers. The stories' unrecognizable urban landscapes can thus be interpreted as the dystopian counter-image of the bright

${ }^{24}$ Quim Monzó, L'illa de Maians, p. 14. 
and charming images associated with the new Barcelona. These uninterrupted but also self-enclosed landscapes unveil the ongoing process of commodification of spaces and territories, which, in their turn, interpellate the people who inhabit them as equally generic individuals with no possible singular personalities. These totally commodified urban spaces incorporate people as serialized figures and stereotypes and they ultimately commodify them altogether.

The destabilizing effects that the expansion of commodification causes over people's lives can be seen in another story, titled «La inestabilitat» [«Instability»]. In it, a man has his car radio stolen continuously, so he decides to carry it with him every time he leaves the car. Then they call him from a television contest to ask him a couple of questions for the show. He answers them correctly and he is awarded a beach apartment, where he meets a neighbor whose husband suddenly dies. Then he marries her, they have two children and the story ends enigmatically one morning while he is getting in his car:

«Encaixa la ràdio a lloc, l'engega, sintonitza una emisora, es cobreix la cara $\mathrm{amb}$ les dues mans i, amb totes les forces de què és capaç, intenta plorar, però no se'n surt mai. $>25$

[He returns the radio to its place, turns it on, tunes into a radio station, covers his face with both of his hands and, with maximum effort, he tries to cry, but he never can.]

This fast-paced story, also set in a series of standardized urban spaces, describes the life of a contemporary man as ruled by an unpredictable game of chance - a symbolic correspondence of the constantly changing world as dominated by mobile capital and infinite commodity exchange.

Despite full commodification, in the end this postmodern man struggles against the waning of his affect by attempting to cry. And, even if he cannot do it, his attempt reveals a moment of recognition of the real conditions of his situation. Even if the possibility of retrieving the waned affect proves to be impossible, or precisely because of it, this final act uncovers the totally commodified space that surrounds and also constitutes him. It is to the extent that he fails in his attempt to cry, which confirms that commodification has occupied his very inner self, which he succeeds in disrupting this commofidifying process. His failure to cry corroborates the expansion of commodification and at the same time tears it apart. It proves it to be

${ }^{25}$ Quim Monzó, El perqué de tot plegat, p. 76 
both inexorable and false. The dry tears, like the flaccid penis of «La gelosia», are the final remnants that attest the impossibility of a non-commodified existence or a non-objectified exchange. But, in their very constitution as residues, they set, if not an outside, at least an internal limit to commodification, which consequently uncovers it as a historical - not inexorable or inescapable - process.

But there is still another limit to commodification. By portraying it as a thorough and unmitigated phenomenon, Monzó's stories raise the question of whether they are themselves a commodified product, in the function of, for instance, a cultural representation serving in some way the marketing of Barcelona, or whether they escape to a certain extent the inexorability of their context and their content. But these two options entail a paradox. On the one hand, if the stories are commodified artifacts, then they cannot be accurate and comprehensive accounts of full commodification--they would be merely reproducing its internal logic, with no potential to distance themselves from it, let alone disrupt it or oppose it. On the other hand, if the narratives remain outside commodification, then they are also inaccurate accounts, as they constitute the proof that commodification is not absolute. However, what really escapes the foreclosure of full commodification is precisely this paradox, that is, the stories' unspoken oscillation between the two possibilities. The undecidability contained in them asserts the impossibility of escaping commodification but also posits an internal and contradictory limit to it represented by the very existence of the stories. Their very presence subverts the inexorability of the process that they describe. Their depiction of the city as a totally enclosed space, with no past, no future, and no outside, undermines the very inevitability of this dystopian but all too real state of things. Therefore, the process of commodification is uncovered as a historical one - an absolute one but nonetheless historical. Which, logically, opens up the possibility of a different historical situation: the possibility of a non-commodified space beyond the current conditions of production. The stories' portrait of Barcelona as an unrecognizable city subsumed to a global homogenizing logic of production, paradoxically offers us a glimpse of the possibility of an undetermined, yet radically different future.

In this sense, Monzó's Barcelona corresponds to what architect Rem Koolhaas has called "the Generic City" to describe the inescapable homogenization of spaces in contemporary cities. According to him, the restoration of historical buildings and the production of city identity are two of the main agents of the homogenizing Generic, as it is precisely through

«... the relentless conversion of utilitarian space into "public" space, pedestrianization, the creation of new parks, planting, bridging, exposing, the 
systematic restoring of historic mediocrity, [that] all authenticity is relentlessly evacuated.»>

Remarkably, Koolhaas mentions Barcelona as an exemplary case of this process:

«Sometimes an old, singular city, like Barcelona, by oversimplifying its identity, turns Generic. It becomes transparent, like a logo. The reverse never happens $\ldots$ at least not yet.> 26

The transformation of a generic or commodified space into a singular one «never happens ... at least not yet.» But let's hope that the detection of the hidden structural logics of a process of urban change, and the search for an internal limit to their commodifying effects, as found in Monzó's fiction, constitutes a first step to help future singularity occur.

\footnotetext{
${ }^{26}$ Rem Koolhaas, Bruce Mau, Jennifer Sigler, and Hans Werlemann, Small, Medium, Large, Extra-large: Office for Metropolitan Architecture, Rem Koolhaas, and Bruce Mau, New York: Monacelli Press, 1995, p.1249 and p.1250. Koolhaas often refers to the conspicuous commercialization of contemporary Barcelona. In "Junkspace», where he looks at the different forms through which spaces have become commodified and serialized, he mentions the city: «Through Junkspace old aura is transfused with new luster to spawn sudden commercial viability: Barcelona amalgamated with the Olympics [...]», in Judy Chung, Chuihua, and Sze Tsung Leong, eds, Harvard Design School Guide to Shopping, Köln: Taschen, 2001, p.416. Or, in «Miestakes», in Hubert-Jan Henket and Hilde Henen, eds, Back From Utopia: The Challenge of the Modern Movement, Rotterdam: OIO Publishers, 2002, pp. 238-251, he refers to the reconstruction in 198587 of Mies van der Rohe's German Pavilion, directed by architects Ignasi de Solà-Morales, Cristian Cirici, and Fernando Ramos, as an example of modernism commodified by urban marketing.
} 